\title{
Spring-Interseeded Winter Rye Seeding Rates Influence Weed Control and Organic Soybean Yield
}

\author{
Kelly A. Nelson, ${ }^{1}$ Reid J. Smeda, ${ }^{1}$ and Randall L. Smoot ${ }^{2}$ \\ ${ }^{1}$ Division of Plant Sciences, University of Missouri, Columbia, MO 65211, USA \\ ${ }^{2}$ Greenley Research Center, University of Missouri, Novelty, MO 63460, USA \\ Correspondence should be addressed to Kelly A. Nelson, nelsonke@missouri.edu
}

Received 12 January 2011; Revised 25 March 2011; Accepted 27 March 2011

Academic Editor: J. K. Ladha

Copyright ( 2011 Kelly A. Nelson et al. This is an open access article distributed under the Creative Commons Attribution License, which permits unrestricted use, distribution, and reproduction in any medium, provided the original work is properly cited.

Field research in 2002 and 2003 evaluated spring-interseeded winter rye (Secale cereale L.) at 67, 134, or $200 \mathrm{~kg} \mathrm{ha}^{-1}$ at two soybean (Glycine max (L.) Merr.) row spacings (19- and 76-cm) on weed control, yield, and gross margins. Based on regression analysis, wide-row $(76-\mathrm{cm})$ soybean grain yield and gross margins were greatest when winter rye was interseeded at 114 and $106 \mathrm{~kg} \mathrm{ha}{ }^{-1}$, respectively. Yields and gross margins for wide-row soybean were 8 to $55 \%$ greater than narrow-row (19-cm) soybean seeded at 494,000 or 742,000 seeds $\mathrm{ha}^{-1}$ which was probably due to flexibility for implementing cultivation. As interseeded rye rates increased from 67 to $200 \mathrm{~kg} \mathrm{ha}^{-1}$, yields and gross margins for narrow-rows decreased. Soybean row spacing had minimal impacts on specific weed species and total weed biomass or density. The use of wide-row soybean and spring-interseeded rye at $67 \mathrm{~kg} \mathrm{ha}^{-1}$ was more cost-effective compared to narrow rows.

\section{Introduction}

Demand for organic crop production in the USA has increased, resulting in over 4.2 million certified organic crop production hectares in 2005 [1]. In 2005, more than $55 \%$ of the organic field crop production hectares in Missouri were soybean, while Missouri ranked 23rd in the USA for the number of certified organic producers in 2007 [1]. Missouri farmers have noted increased profit margins with organic versus conventional crop production systems in mid-west states $[2,3]$ and are more likely to consider using land previously set aside in the conservation reserve program for organic crop production [4]. Claypan soils in Missouri enrolled in the conservation reserve program generally are highly erodible. Using preplant primary tillage followed by two or three rotary hoeings and at least two in-crop cultivations has been an acceptable method of controlling weeds in organic soybeans [4-6]. Long-term research indicated that tillage-intensive, organic systems had greater soil benefits than conventional no-till on drought-prone, erodible soils [7]. However, the intensity of labor and tillage required for organic crop production has limited the widespread adoption of organic soybean production, especially on highly erodible soils.

Weed interference has affected soybean yields more in organic production systems than in conventional systems $[8,9]$, especially in narrow rows [10]. Weed control using companion crops such as winter rye seeded and narrowrow soybean was described in the 1950s [11]. Winter rye was preferred as a companion crop over wheat (Triticum aestivum L.). Cover crops such as winter rye have been used to suppress weeds, reduce soil erosion, reduce surface water runoff, increase organic carbon, and increase beneficial microbial populations $[8,12-14]$. Typically, winter rye is seeded in the fall and desiccated with herbicides or incorporated with tillage to suppress winter annual weeds in row-crops [12, 15-17]. Winter rye residue suppresses weeds physically through interference and chemically with allelopathic compounds that delay weed emergence [18-20]. However, winter rye residue cannot provide full-season weed suppression $[16,17,21,22]$. When used in an organic production system, winter rye has suppressed weeds through physical interference as a living mulch, but this system may also decrease crop grain yields $[6,11,23]$. Management of rye 
TABLE 1: Field information and selected management practices in 2002 and 2003.

\begin{tabular}{lcc}
\hline Field information and management practices & 2002 & 2003 \\
\hline Tillage & & Moldboard plow \\
Fall tillage & Chisel plow & $1 \mathrm{x}$ \\
Spring disk-harrow & $-{ }^{a}$ & $3 \mathrm{x}$ \\
Spring field cultivated & $3 \mathrm{x}$ & May 29 \\
Soybean planting date & June 5 & Big Bubba \\
Cultivar & Big Bubba & May 29 \\
Winter rye planting date & June 5 & Forage Master \\
Cultivar & Forage Master & June 9, June 16 \\
Rotary hoed $^{\text {b }}$ & June 17, June 22 & VC, V1 \\
Stage of soybean development ${ }^{c}$ & VC, V1 & June 23, July 2, July 20 \\
Row cultivated & June 25, July 3, July 18 & V3, V4, V6 \\
Stage of soybean development & V3, V5, V7 & October 12 \\
Harvest date & October 10 \\
\hline
\end{tabular}

${ }^{a}$ No treatment was applied.

${ }^{b}$ All treatments except the weedy check.

${ }^{\mathrm{c}}$ As described in Fehr and Caviness [24].

${ }^{\mathrm{d}}$ All 76 -cm wide-row plots except the weedy check.

using cultivation was necessary to minimize yield reductions, particularly in dry years, because no alternative methods exist to control rye in organic soybean.

Winter rye requires a vernalization period before jointing and flowering, and it commonly dies under summer stress $[11,21]$. Interseeding winter rye in spring may promote a synergistic relationship with soybean, while restricting rye to vegetative growth. In this condition, rye may serve as a living mulch that suppresses weeds and minimizes soil erosion, while exerting minimal competition with soybean. Using winter rye in narrow-row soybean may allow farmers to increase production efficiency by reducing the time allotted to cultivation. In separate experiments, spring-interseeded winter rye at $125 \mathrm{~kg} \mathrm{ha}^{-1}$ in wide $(76-\mathrm{cm})$ and narrow (19$\mathrm{cm}$ ) rows reduced soybean yield by 17 to $27 \%$ in two of three years in the narrow-row experiment and in all three years in the wide-row experiment [6]. No known research has evaluated rates of rye or compared the cost-effectiveness of rye interseeded in wide- and narrow-row soybean. The objective of this research was to evaluate spring-seeded winter rye seeding rates on control of weeds, crop response, and gross margins of organic soybean in different row spacings.

\section{Materials and Methods}

Field research was conducted at the University of Missouri Greenley Research Center at Novelty $\left(40^{\circ} 01^{\prime} \mathrm{N}, 92^{\circ} 11^{\prime} \mathrm{W}\right)$ in 2002 and 2003. Research was arranged in a split-plot design with four replications in 2002 and three replications in 2003. The main plot was soybean row spacing [76-cm wide row spacing seeded at 346,000 seeds ha ${ }^{-1}$ (wide-row), 19-cm wide row spacing seeded at 494,000 seeds ha ${ }^{-1}$ (NRL $=$ Narrow-row with low seeding rate), and $19-\mathrm{cm}$ wide row spacing seeded at 741,000 seeds ha ${ }^{-1}(\mathrm{NRH}=$ Narrowrow with high seeding rate)], and the subplot was winter rye seeding rate $\left(67,134\right.$, and $200 \mathrm{~kg} \mathrm{ha}^{-1}$, weedy check with no winter rye, and weed-free check with no winter rye). Subplots were 3 by $15.2 \mathrm{~m}$. A planter (John Deere 7000, Deere and Co., 501 River Drive, Moline, IL 612651100) and drill (Great Plains Solid Stand 10, Great Plains Manufacturing Inc., P.O. Box 218, Assaria, KS 67416) seeded "Big Bubba" soybean in wide- $(76-\mathrm{cm})$ and narrow-rows $(19-\mathrm{cm})$, respectively. The seeding rate in $19-\mathrm{cm}$ rows was greater than the rate in wide rows, because higher seeding rates are recommended for narrow-row drill seeded soybean [25]. Two seeding rates were used in narrow-row soybean to evaluate the cost-effectiveness of a higher seeding rate. "Forage Master" winter rye was broadcast seeded with a hand spreader immediately following soybean seeding. Winter rye emergence in the spring was excellent in both years (visual observation).

The soil was a Putnam silt loam (fine, montmorillonitic, mesic Mollic Albaqualf) with pH 6.7 and $2.9 \%$ organic matter in both years. Soil texture was $13 \%$ sand, $62 \%$ silt, and $25 \%$ clay. Soil test values for $\mathrm{P}$ and $\mathrm{K}$ at this site [26] were in the medium to very-high range, based on Missouri soil test interpretations [27] and required no additional fertilizer inputs for these experiments. Field information and selected management practices are listed in Table 1. Wide-row soy bean was rotary hoed twice and cultivated three times, while narrow-row soybean was rotary hoed twice. The site had been in an organic corn soybean rotation for five years before this research. Weed species in the field included jimsonweed (Datura stramonium L.), common waterhemp (Amaranthus rudis Sauer), common cocklebur (Xanthium strumarium L.), common lambsquarters (Chenopodium album L.), giant foxtail (Setaria faberi Herrm.), and ivyleaf morningglory (Ipomoea hederacea (L.) Jacq.). Weather conditions for the two study years were previously reported [28]. Precipitation from seeding until 1 October was $232 \mathrm{~mm}$ in 2002 and 
TABLE 2: Effect of winter rye seeding rate on soybean, winter rye, jimsonweed, and total weed fresh weight biomass at physiological maturity in 2002 and 2003. Data were combined over years and row spacings unless denoted otherwise.

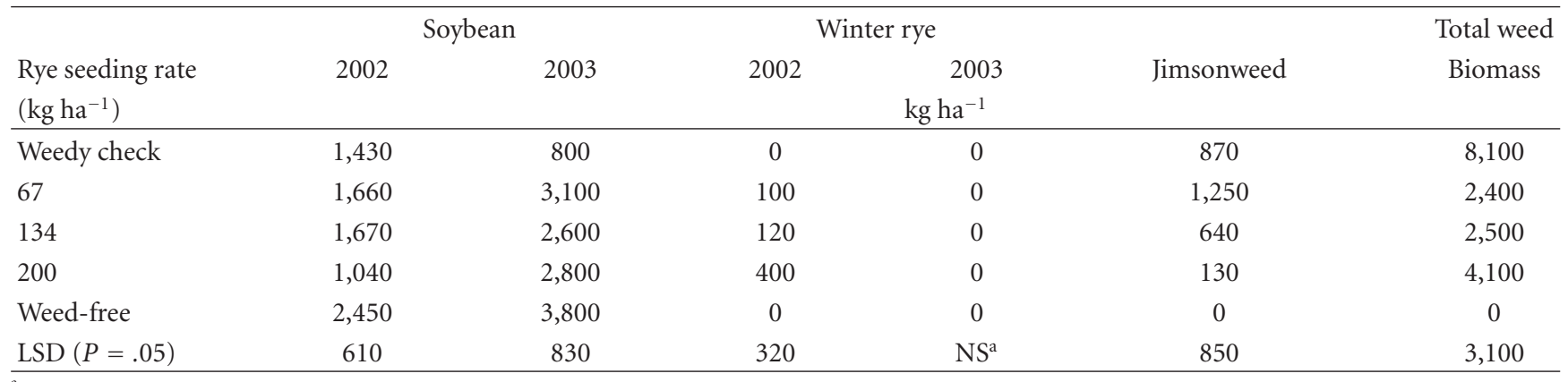

${ }^{a}$ Abbreviations: NS: nonsignificant.

$574 \mathrm{~mm}$ in 2003 with an average precipitation of $527 \mathrm{~mm}$ from 1 May to 1 October during the past decade (20002009). Individual weed species and soybean were harvested, counted, separated, and weighed on 3 September 2002, and 12 September 2003, from two randomly placed 30 by $76 \mathrm{~cm}$ quadrats near physiological maturity. Total weed fresh weight biomass or density was the sum of individual weeds present in the quadrats. Two rows of wide-row soybean and a 1.5-m width of the narrow-row soybean were harvested from the entire plot length with a small-plot combine (Kincaid Equipment Manufacturing, P.O. Box 400, Haven, KS 47543) and moisture adjusted to $13 \%$.

We performed an economic analysis to evaluate gross margins for spring-seeded winter rye rates in wide- and narrow-row soybean. The gross margin was the difference between gross receipts and weed-management costs $[29,30]$. Gross receipts were the product of crop yield and an assumed market price of $\$ 37.05 \mathrm{ha}^{-1}$ [31]. Weed management costs were the sum of planting $\left[\$ 25.94 \mathrm{ha}^{-1}\right.$ for drill $(19-\mathrm{cm}$ rows) and $\$ 25.19 \mathrm{ha}^{-1}$ for planter $(76-\mathrm{cm}$ rows) seeded in conventionally tilled soil], soybean seed $\left(\$ 0.72 \mathrm{~kg}^{-1}\right.$ adjusted to the seeding rate and 5730 seeds $\mathrm{kg}^{-1}$ ), cultivation ( $\$ 15.61 \mathrm{ha}^{-1}$ for a row cultivator and $\$ 11.01 \mathrm{ha}^{-1}$ for rotary hoeing), and broadcasted winter rye seed $\left(\$ 0.41 \mathrm{~kg}^{-1}\right.$ plus broadcast application at $\left.\$ 12.35 \mathrm{ha}^{-1}\right)[32,33]$. In addition, we tested the economic benefit of using different row spacings with spring-seeded winter rye at $67 \mathrm{~kg} \mathrm{ha}^{-1}$ similar to other research $[34,35]$. We performed the test using the weed management costs above for different soybean seeding costs from $\$ 0.72$ to $\$ 2.16 \mathrm{~kg}^{-1}$ ( $\$ 0.33$ to $\$ 0.98 \mathrm{lb}^{-1}$ ) and soybean grain receipt scenarios from $\$ 0.55$ to $\$ 1.65 \mathrm{~kg}^{-1}$ ( $\$ 15$ to $\$ 45 \mathrm{bu}^{-1}$ ) to include current and possible price increases in the organic market [1].

An analysis of variance was conducted using the general linear model procedure (PROC GLM) [36]. Data were combined over years and main effects of row spacing or winter rye seeding rate presented when interactions were not observed. Mean separation for individual treatment differences was performed using Fisher's Protected LSD at $P=.05$. Total weed density main effects were subjected to F-Max test for homogeneity of variance and combined over years [37]. Regression analysis was performed using best fit analysis determined with SigmaPlot (Version 10.0). Standard errors of the yield and gross margin means were determined using SAS [36].

\section{Results and Discussion}

In both years, rye seeding rate influenced both biomass (Table 2) and density (Table 3 ) of soybean and weeds. Winter rye emergence was excellent and remained vegetative in 2002, but died in the summer of 2003 as reported in other research [6]. Due to the persistence of winter rye during the summer of 2002, it may act as a weed during a drier year and reduce yields. The main effects for winter rye seeding rate on plant biomass and density are reported since there was no interaction with row spacing except for common waterhemp density, which related primarily to weed density differences in the weedy check. Interactions between years were observed for soybean and winter rye data, since rainfall in 2002 was $295 \mathrm{~mm}$ below normal and in 2003 (47 $\mathrm{mm}$ above normal) was uniformly distributed throughout the growing season [28]. As winter rye seeding rate increased, soybean fresh weight (Table 2 ), and density (Table 3 ) decreased compared to the weed-free control. Our finding of a reduction in soybean growth under low precipitation conditions in 2002 was consistent with reports by other researchers $[6,11]$ and likely reflects competition between rye and soybean for available moisture.

Reductions in weed biomass and density also were strongly influenced by the presence of rye plus mechanical weed removal compared to the weedy check (Tables 2 and 3 ). At a rye seeding rate up to $200 \mathrm{~kg} \mathrm{ha}^{-1}$, total weed biomass and weed density were lower compared to the weedy check. Winter rye interseeded at $67 \mathrm{~kg} \mathrm{ha}^{-1}$ had $99 \%$ greater jimsonweed fresh weights than higher seeding rates $\left(200 \mathrm{~kg} \mathrm{ha}^{-1}\right)$. However, there was no significant difference among winter rye seeding rates on the biomass of common waterhemp, common cocklebur, common lambsquarters, giant foxtail, or ivyleaf morningglory fresh weights (data not presented). Similarly, there was no significant effect of winter rye seeding rates on common waterhemp, common cocklebur, common lambsquarters, jimsonweed, giant foxtail density (data not presented), or common waterhemp (Table 3). The interaction between rye seeding rate and soybean row spacing on common waterhemp density was due primarily 
TABLE 3: Effect of winter rye seeding rate on soybean, winter rye, common waterhemp, ivyleaf morningglory, and total weed density in 2002 and 2003. Data were combined over years and row spacings unless denoted otherwise.

\begin{tabular}{|c|c|c|c|c|c|c|c|c|c|}
\hline \multirow[b]{2}{*}{$\begin{array}{l}\text { Rye seeding rate } \\
\left(\mathrm{kg} \mathrm{ha}^{-1}\right)\end{array}$} & \multicolumn{2}{|c|}{ Soybean } & \multicolumn{2}{|c|}{ Winter rye } & \multicolumn{3}{|c|}{ Common waterhemp } & \multirow{2}{*}{$\begin{array}{c}\text { Ivyleaf } \\
\text { morningglory }\end{array}$} & \multirow{2}{*}{$\begin{array}{c}\text { Total weed } \\
\text { density }\end{array}$} \\
\hline & 2002 & 2003 & 2002 & $2003^{b}$ & Wide-row & $\begin{array}{c}\text { Narrow-row low } \\
\text { No. } \mathrm{m}^{-2}\end{array}$ & Narrow-row high & & \\
\hline Weedy check & 32 & 17 & 0 & 0 & 82 & 36 & 55 & 5 & 86 \\
\hline 67 & 35 & 39 & 4 & 0 & 1 & 10 & 3 & 0 & 20 \\
\hline 134 & 33 & 32 & 9 & 0 & 1 & 5 & 6 & 1 & 21 \\
\hline 200 & 27 & 32 & 22 & 0 & 0 & 3 & 1 & 5 & 30 \\
\hline Weed-free & 33 & 37 & 0 & 0 & 0 & 0 & 0 & 0 & 0 \\
\hline $\operatorname{LSD}(P=.05)$ & NS & 8 & 1 & $\mathrm{NS}^{\mathrm{a}}$ & & 19 & & 4 & 17 \\
\hline
\end{tabular}

abbreviations: NS: nonsignificant.

${ }^{b}$ Winter rye emerged in the spring and died over the summer as in other research [6].

TABLE 4: Effect of soybean row spacing and narrow-row (19-cm) seeding rate on soybean and common lambsquarters fresh weights in 2002 and 2003. Data were combined over years and winter rye seeding rates unless denoted otherwise.

\begin{tabular}{|c|c|c|c|c|}
\hline \multirow[b]{2}{*}{$\begin{array}{l}\text { Row spacing } \\
(\mathrm{cm})\end{array}$} & \multirow[b]{2}{*}{$\begin{array}{l}\text { Seeding rate } \\
\left(\text { seeds ha }{ }^{-1}\right)\end{array}$} & \multicolumn{2}{|c|}{ Soybean } & \multirow{2}{*}{$\begin{array}{c}\text { Common } \\
\text { lambsquarters } \\
a^{-1}\end{array}$} \\
\hline & & 2002 & $\begin{array}{r}2003 \\
\mathrm{~kg}\end{array}$ & \\
\hline 76 & 346,000 & 1,400 & 3,200 & 50 \\
\hline 19 & 494,000 & 1,850 & 1,700 & 420 \\
\hline 19 & 741,000 & 1,700 & 3,000 & 20 \\
\hline $\operatorname{LSD}(P=.05)$ & & NS & 960 & 240 \\
\hline
\end{tabular}

to differences in the weedy check compared to interseeded rye treatments. Ivyleaf morningglory density increased as winter rye seeding rate increased from 67 to $200 \mathrm{~kg} \mathrm{ha}^{-1}$ which was probably due to late germination of this largeseeded broadleaf weed, but no differences in biomass were detected $(P=.15)$. Winter rye biomass (Table 2$)$ and density (Table 3 ) increased as seeding rate increased compared to the weedy check in a dry year (2002), while winter rye did not survive during the summer months in a year with higher rainfall (2003) due to increased competition of soybean.

The effect of soybean row spacing on plant fresh weight biomass and density was similar; therefore, we present only biomass data (Table 4). Soybean fresh weights were not affected by row spacing in 2002, but fresh weights were 43 to $47 \%$ lower in NRL soybean in 2003. Common lambsquarters fresh weight was 88 to $95 \%$ greater in NRL than NRH seeding rates. However, we found no significant effect of row spacing on giant foxtail $(P=.41)$, common cocklebur $(P=.40)$, jimsonweed $(P=.16)$, ivyleaf morningglory $(P=.45)$, common waterhemp $(P=.32)$, winter rye $(P=.88)$, and total weed biomass $(P=.24)$ (data not presented).

Yields in the weedy check were ranked NRH $\left(1130 \mathrm{kgha}^{-1}\right) \geq \mathrm{NRL}\left(1000 \mathrm{kgha}^{-1}\right)=$ wide rows $\left(790 \mathrm{~kg} \mathrm{ha}^{-1}\right.$ ) (Figure 1). Yields were similar between row spacings in weed-free plots in the absence of rye. Based on the yield regression equation, the optimal spring rye seeding rate for wide rows was $114 \mathrm{~kg} \mathrm{ha}^{-1}$. Winter rye interseeded at $67 \mathrm{~kg} \mathrm{ha}^{-1}$ in narrow-row soybean reduced

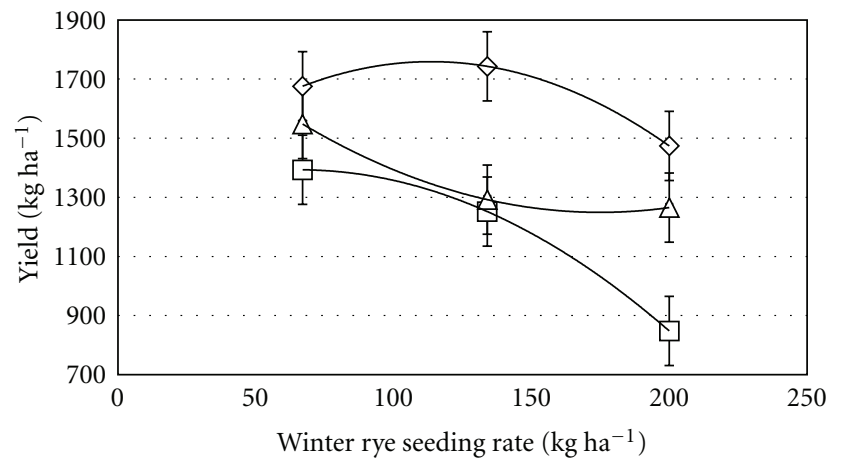

$\diamond 76 \mathrm{~cm}$ at 346000 seeds ha-1
$\square 19 \mathrm{~cm}$ at 494000 seeds ha-1
$\Delta 19 \mathrm{~cm}$ at 741000 seeds $\mathrm{ha}^{-1}$

FIGURE 1: Effect of spring-interseeded winter rye rate on wide- (76$\mathrm{cm})$ and narrow-row $(19-\mathrm{cm})$ soybean grain yield. Fitted lines are for wide rows (open diamonds, $y=-0.0382 x^{2}+8.6867 x+1265.3$, $R^{2}=0.99$ ), narrow rows at 494,000 seeds ha ${ }^{-1}$ (NRL, open squares, $\left.y=-0.0301 x^{2}+3.949 x+1263.8, R^{2}=0.99\right)$, and narrow rows at 741,000 seeds ha ${ }^{-1}$ (NRH, open triangles, $y=0.0256 x^{2}-8.9692 x+$ $\left.2033.8, R^{2}=0.99\right)$. The vertical bars represent the standard errors of the means. The weedy check grain yields were 790, 1000, and $1130 \mathrm{~kg} \mathrm{ha}^{-1}$ in wide-row, NRL, and NRH systems, respectively. Weed-free grain yields were 1900,1740 , and $1910 \mathrm{~kg} \mathrm{ha}^{-1}$ in widerow, NRL, and NRH systems, respectively. LSD $(P=.05)$ was $300 \mathrm{~kg} \mathrm{ha}^{-1}$.

yield 360 to $380 \mathrm{~kg} \mathrm{ha}^{-1}$ compared to the weed-free control. As the seeding rate of rye increased from 67 to $200 \mathrm{~kg} \mathrm{ha}^{-1}$, soybean yield decreased in narrow rows likely due to higher total weed biomass (Table 2) and density (Table 3 ) as the rye seeding rate increased. Soybean yield increased in narrow rows when the soybean seeding rate increased from 494,000 to 741,000 seeds ha $^{-1}$ (Figure 1). This was similar to other research in which the optimal seeding rate in narrow-row $(19-\mathrm{cm})$ organic soybean was approximately 889,200 seeds ha ${ }^{-1}$ in 2 of 3 years [6]. Winter rye at $67 \mathrm{~kg} \mathrm{ha}^{-1}$ resulted in the highest yield of narrow-row soybean seeded at either rate. This was similar to observations and a single siteyear evaluating winter rye seeding rates in Minnesota [11]. 


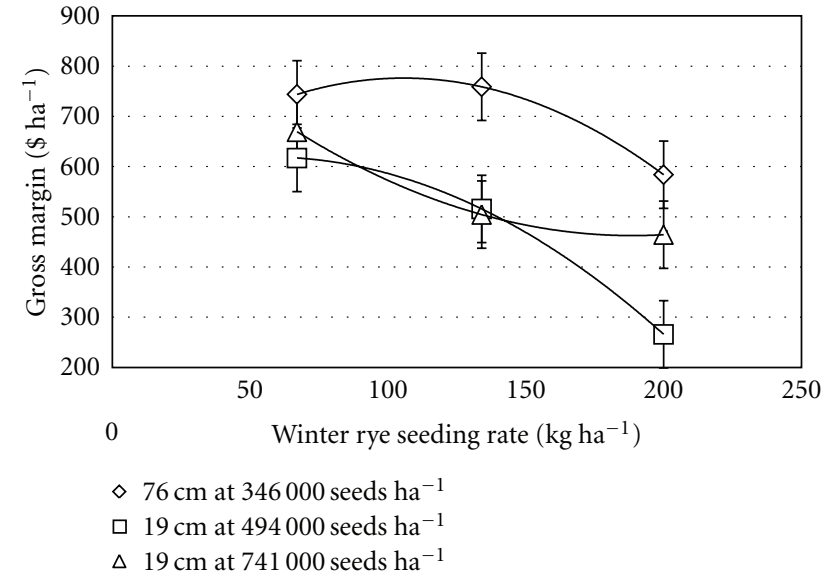

FIgURE 2: Gross margins for spring-interseeded winter rye rates for wide $(76-\mathrm{cm})$ and narrow-row $(19-\mathrm{cm})$ soybean. The gross margin was calculated as the difference between gross receipts and weed management costs. Fitted lines describing seeding rates are for wide rows (open diamonds, $y=-0.0216 x^{2}+4.5697 x+534.71$, $\left.R^{2}=0.99\right)$, narrow-row low (NRL, open squares, $y=-0.0171 x^{2}+$ $\left.1.9141 x+565.4, R^{2}=0.99\right)$, and narrow-row high $(\mathrm{NRH}$, open triangles, $\left.y=0.0139 x^{2}-5.2651 x+959.5, R^{2}=0.99\right)$. The vertical bars represent the standard errors of the means. The weedy check gross margin was $\$ 367.04 \mathrm{ha}^{-1}, \$ 461.84 \mathrm{ha}^{-1}$, and $\$ 502.45 \mathrm{ha}^{-1}$ for wide-row, NRL, and NRH systems, respectively. $\operatorname{LSD}(P=.05)$ was $\$ 175 \mathrm{ha}^{-1}$.

Thelen et al. [6] reported that rye interseeded at $125 \mathrm{~kg} \mathrm{ha}^{-1}$ consistently reduced yield compared to soybean without winter rye, which was similar to our results with a seeding rate of $134 \mathrm{~kg} \mathrm{ha}^{-1}$. However, the use of cultivation reduced the competitive impact by winter rye in wide rows. Yield differences between wide- and narrow-row organic soybean with winter rye were not as great as other research evaluating row spacings in the absence of winter rye [10].

Although soybean yield is important, profitability also depends upon minimizing crop inputs. Based on gross margins, the optimal winter rye seeding rate was $106 \mathrm{~kg} \mathrm{ha}^{-1}$ for wide rows (Figure 2), while the highest gross margins came from rye at $67 \mathrm{~kg} \mathrm{ha}^{-1}$ for narrow-row soybean seeded at either rate. Since spring-seeded winter rye at $67 \mathrm{~kg} \mathrm{ha}^{-1}$ was nearly the optimal seeding rate for both wide- and narrow-row organic soybean yields (Figures 1 and 2), we performed additional economic analysis to evaluate the impact of various seed cost and soybean return scenarios (Figure 3) similar to other research [30, 34, 35]. As seed cost increased from $\$ 0.72$ to $\$ 2.16 \mathrm{~kg}^{-1}$, gross margins decreased from $\$ 85$ to $\$ 185 \mathrm{ha}^{-1}$ depending upon the row spacing. Although wide-row soybean had additional costs associated within row cultivation, gross margins were $\$ 75$ to $\$ 470 \mathrm{ha}^{-1}$ greater than narrow-row soybean, regardless of seeding rate. While increased seed costs were realized with NRH compared to NRL soybean, gross margins were $\$ 20$ to $220 \mathrm{ha}^{-1}$ greater when soybean were seeded in the NRH system. The only exception was when soybean seed costs were $\$ 2.16 \mathrm{~kg}^{-1}$ and returns were $\$ 0.55 \mathrm{~kg}^{-1}$, and NRL had gross margins that were $\$ 10 \mathrm{ha}^{-1}$ greater than NRH.

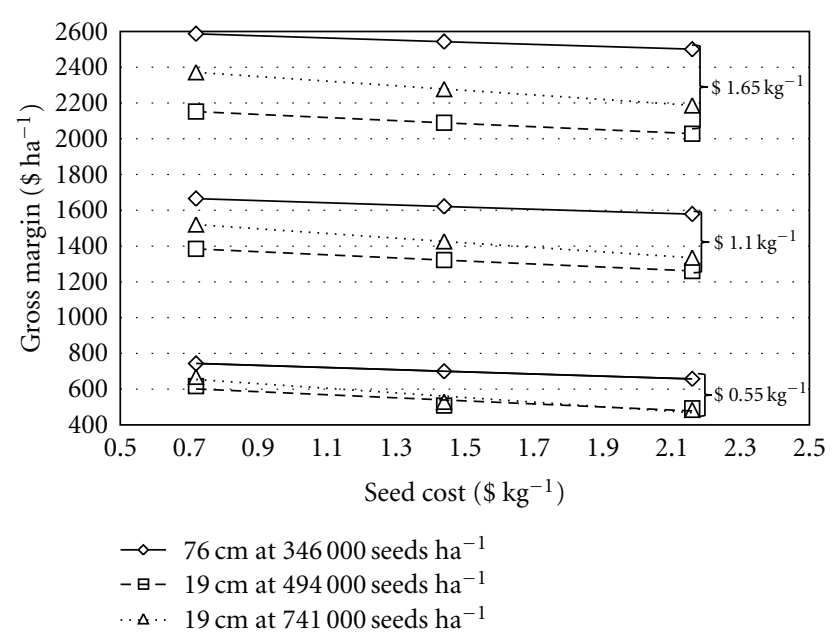

FIgURE 3: Gross margins for spring-interseeded winter rye at $67 \mathrm{~kg} \mathrm{ha}^{-1}$ into wide- $(76-\mathrm{cm})$ and narrow $(19-\mathrm{cm})$ soybean rows for different soybean seed costs from $\$ 0.72$ to $\$ 2.16 \mathrm{~kg}^{-1}$ (\$0.33 to $\left.\$ 0.98 \mathrm{lb}^{-1}\right)$ scenarios and returns for soybean $(\$ 0.55, \$ 1.10$, and $\left.\$ 1.65 \mathrm{~kg}^{-1}\right)\left(\$ 15\right.$ to $\left.\$ 45 \mathrm{bu}^{-1}\right)$.

Wide-row soybean grain yields and gross margins at all interseeded rye rates were 8 to $55 \%$ greater than NRL or NRH. Based on yield and gross margins, the optimal winter rye interseeding rate in wide-row soybean was 106 to $114 \mathrm{~kg} \mathrm{ha}^{-1}$ for the rye rates evaluated in our research, though other research found that a higher interseeded rye rate $\left(125 \mathrm{~kg} \mathrm{ha}^{-1}\right)$ consistently reduced soybean yield [6]. None of the narrow-row treatments in this research resulted in grain yields equivalent to wide-row soybean, which was probably due to flexibility for implementing cultivation in wide rows. The utilization of winter rye in narrow-row, organic soybean production did not provide adequate grain yields or gross margins to justify conversion from wide- to narrow-row production. Risk associated with narrow-row soybean and spring-interseeded rye as a weed management system preclude the adoption of narrow-row soybean in an organic soybean production system since narrow-row soybean rules out using mechanical weed control. In North Carolina, soybean seeding rates up to 556,000 seeds ha $^{-1}$ in organic soybean production systems increased grain yields and profitability in 76-cm rows [38], while delayed seeding of rye after soybean were established maximized yields compared to seeding at the time soybeans were planted [23]. Seeding a companion crop up to $18 \mathrm{~d}$ before soybean planting was not recommended for effective weed control [11]. Additional research is needed to discover whether it is possible to increase soybean yield and consistency of this weed management system. A logical next step would be to look at integrating increased soybean seeding rates with interseeded rye at rates less than $110 \mathrm{~kg} \mathrm{ha}^{-1}$ in wide-row soybean and delayed spreading of interseeded rye in wide or narrow rows. 


\section{Abbreviations}

NRL: $19-\mathrm{cm}$ wide rows seeded at 494,000 seeds $\mathrm{ha}^{-1}$

NRH: $19-\mathrm{cm}$ wide rows seeded at 742,000 seeds $\mathrm{ha}^{-1}$.

\section{Acknowledgments}

The authors would like to thank M. Jones, D. Harder, and S. Devlin for their technical assistance, and the Missouri Soybean Merchandising Council for partial funding of this research.

\section{References}

[1] USDA Economic Research Service, "Organic production," January 2010, http://www.ers.usda.gov/data/organic/.

[2] D. W. Archer, A. A. Jaradat, J. M. F. Johnson et al., "Crop productivity and economics during the transition to alternative cropping systems," Agronomy Journal, vol. 99, no. 6, pp. 15381547, 2007.

[3] M. A. Cavigelli, B. L. Hima, J. C. Hanson, J. R. Teasdale, A. E. Conklin, and Y. C. Lu, "Long-term economic performance of organic and conventional field crops in the mid-Atlantic region," Renewable Agriculture and Food Systems, vol. 24, no. 2, pp. 102-119, 2009.

[4] K. Delate, C. A. Cambardella, and D. L. Karlen, "Transition strategies for Post-CRP certified organic grain production," Crop Management, 2002.

[5] G. T. Place, S. C. Reberg-Horton, and M. G. Burton, "Effects of preplant and postplant rotary hoe use on weed control, soybean pod position, and soybean yield," Weed Science, vol. 57, no. 3, pp. 290-295, 2009.

[6] K. D. Thelen, D. R. Mutch, and T. E. Martin, "Utility of interseeded winter cereal rye in organic soybean production systems," Agronomy Journal, vol. 96, no. 1, pp. 281-284, 2004.

[7] J. R. Teasdale, C. B. Coffman, and R. W. Mangum, "Potential long-term benefits of no-tillage and organic cropping systems for grain production and soil improvement," Agronomy Journal, vol. 99, no. 5, pp. 1297-1305, 2007.

[8] M. A. Cavigelli, J. R. Teasdale, and A. E. Conklin, "Longterm agronomic performance of organic and conventional field crops in the mid-Atlantic region," Agronomy Journal, vol. 100, no. 3, pp. 785-794, 2008.

[9] J. L. Posner, J. O. Baldock, and J. L. Hedtcke, "Organic and conventional production systems in the Wisconsin integrated cropping systems trials: I. Productivity 1990-2002," Agronomy Journal, vol. 100, no. 2, pp. 253-260, 2008.

[10] D. Kluchinski and J. W. Singer, "Evaluation of weed control strategies in organic soybean production," Crop Management, 2005.

[11] R. G. Robinson and R. S. Dunham, "Companion crops for weed control in soybeans," Agronomy Journal, vol. 46, pp. 278 281, 1954.

[12] K. N. Reddy, "Impact of rye cover crop and herbicides on weeds, yield, and net return in narrow-row transgenic and conventional soybean (Glycine max)," Weed Technology, vol. 17 , no. 1 , pp. $28-35,2003$.

[13] M. J. Shipitalo and W. M. Edwards, "Runoff and erosion control with conservation tillage and reduced-input practices on cropped watersheds," Soil and Tillage Research, vol. 46, no. 1-2, pp. 1-12, 1998.
[14] R. M. Zablotowicz, M. A. Locke, and R. J. Smeda, "Degradation of 2,4-D and fluometuron in cover crop residues," Chemosphere, vol. 37, no. 1, pp. 87-101, 1998.

[15] C. H. Koger, K. N. Reddy, and D. R. Shaw, "Effects of rye cover crop residue and herbicides on weed control in narrow and wide row soybean planting systems," Weed Biology and Management, vol. 2, no. 4, pp. 216-224, 2002.

[16] K. N. Reddy, "Effects of cereal and legume cover crop residues on weeds, yield, and net return in soybean (Glycine max)," Weed Technology, vol. 15, pp. 660-668, 2001.

[17] J. R. Teasdale, "Contribution of cover crops to weed management in sustainable agricultural systems," Journal of Production Agriculture, vol. 9, no. 4, pp. 475-479, 1996.

[18] J. P. Barnes and A. R. Putnam, "Evidence for allelopathy by residues and aqueous extracts of rye (Secale cereale)," Weed Science, vol. 34, pp. 384-390, 1986.

[19] N. G. Creamer, M. A. Bennett, B. R. Stinner, J. Cardina, and E. E. Regnier, "Mechanisms of weed suppression in cover cropbased production systems," HortScience, vol. 31, no. 3, pp. 410-413, 1996.

[20] R. J. Smeda and S. C. Weller, "Potential of rye (Secale cereale) for weed management in transplant tomatoes (Lycopersicon esculentum)," Weed Science, vol. 44, no. 3, pp. 596-602, 1996.

[21] C. M. Ateh and J. D. Doll, "Spring-planted winter rye (Secale cereale) as a living mulch to control weeds in soybean (Glycine max)," Weed Technology, vol. 10, no. 2, pp. 347-353, 1996.

[22] K. N. Reddy, R. M. Zablotowicz, M. A. Locke, and C. H. Koger, "Cover crop, tillage, and herbicide effects on weeds, soil properties, microbial populations, and soybean yield," Weed Science, vol. 51, no. 6, pp. 987-994, 2003.

[23] H. Uchino, K. Iwama, Y. Jitsuyama, T. Yudate, and S. Nakamura, "Yield losses of soybean and maize by competition with interseeded cover crops and weeds in organic-based cropping systems," Field Crops Research, vol. 113, no. 3, pp. 342-351, 2009.

[24] W. R. Fehr and C. E. Caviness, "Stages of soybean development," Crop Science, vol. 11, pp. 929-930, 1971.

[25] Z. R. Helsel and J. H. Scott, "Planting practices," in Missouri Soybean Handbook, Z. R. Helsel, D. Esslinger, S. Anad, and G. Laur, Eds., pp. 23-28, University of Missouri Cooperative Extension Service Manual 123, Columbia, Mo, USA, 1987.

[26] K. A. Nelson, P. P. Motavalli, and R. L. Smoot, "Utility of dried distillers grain as a fertilizer source for corn," Journal of Agricultural Science, vol. 1, pp. 3-12, 2009.

[27] D. D. Buchholz, Soil Test Interpretations and Recommendations Handbook, Department of Agronomy, University of Missouri, Columbia, Mo, USA, 1992.

[28] K. A. Nelson and R. L. Smoot, "Twin- and single-row corn production in northeast Missouri," Crop Management, 2009.

[29] K. A. Nelson, "Weed management in wide- and narrowrow glyphosate resistant soybean," Journal of Production Agriculture, vol. 12, no. 3, pp. 460-465, 1999.

[30] K. A. Nelson, C. G. Meinhardt, and R. L. Smoot, "Wheat (Triticum aestivum L.) cultivar selection affects double-crop and relay-intercrop soybean (Glycine max L.) response on claypan soils," International Journal of Agronomy, p. 8, 2010.

[31] R. L. Frerichs, E. D. Nafziger, B. E. Swanson, S. Eckhoff, and D. H. Lattz, Specialty corn and soybean fact sheets, University of Illinois, Urbana-Champaign, Ill, USA, 2000, AE-4736.

[32] R. Plain, J. White, and J. Travlos, Custom rates for farm services in Missouri, MU Extension, University of Missouri, Columbia, Mo, USA, 1997, Ext. G302. 
[33] R. Plain, J. White, and J. Travlos, Custom rates for farm services in Missouri, MU Extension, University of Missouri, Columbia, Mo, USA, 2003, Ext. G302.

[34] K. A. Nelson, R. L. Smoot, and B. A. Burdick, "Seed coat technology affects yields of relay intercrop, full season, and double crop soybean in upstate Missouri," Crop Management, 2010.

[35] A. J. Noellsch, P. P. Motavalli, K. A. Nelson, and N. R. Kitchen, "Corn response to conventional and slow-release nitrogen fertilizers across a claypan landscape," Agronomy Journal, vol. 101, no. 3, pp. 607-614, 2009.

[36] SAS Institute, SAS Users' Guide, SAS Institute, Cary, NC, USA, 2005.

[37] R. O. Kuehl, Statistical Principles of Research Design and Analysis, Duxbury Press, Belmont, Calif, USA, 1994.

[38] G. T. Place, S. C. Reberg-Horton, J. E. Dunphy, and A. N. Smith, "Seeding rate effects on weed control and yield for organic soybean production," Weed Technology, vol. 23, no. 4, pp. 497-502, 2009. 


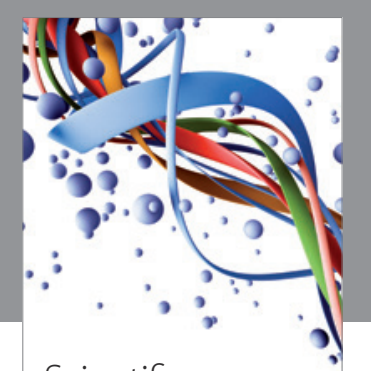

Scientifica
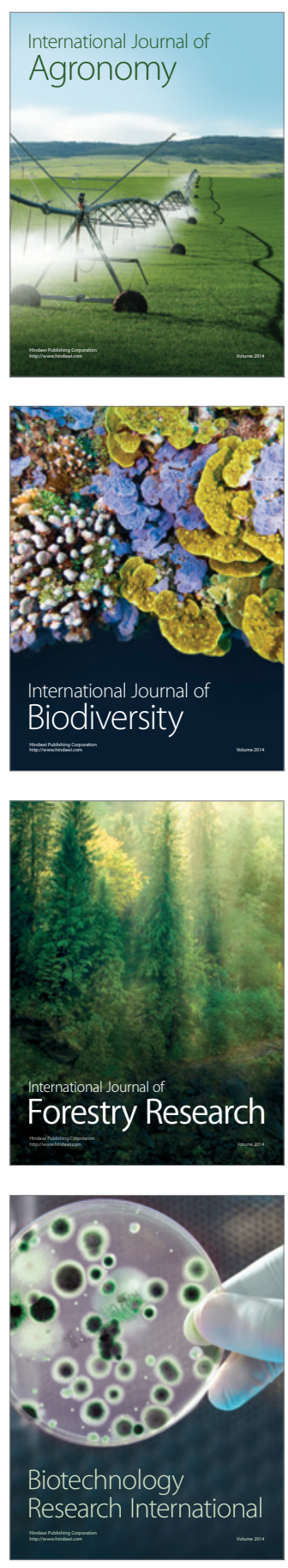
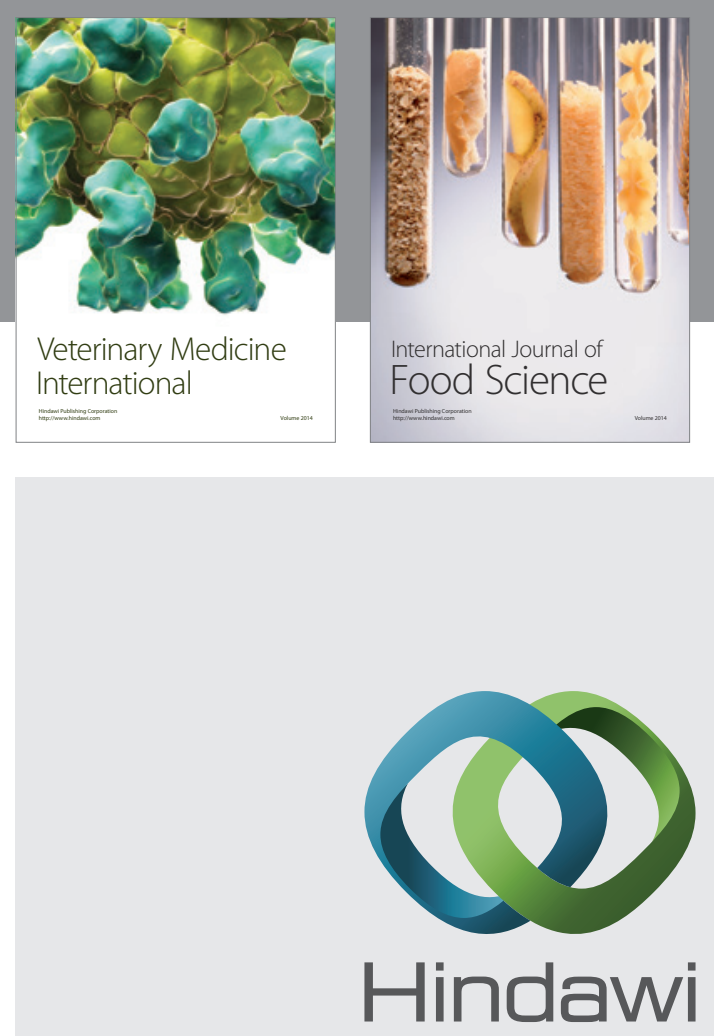

Submit your manuscripts at

http://www.hindawi.com
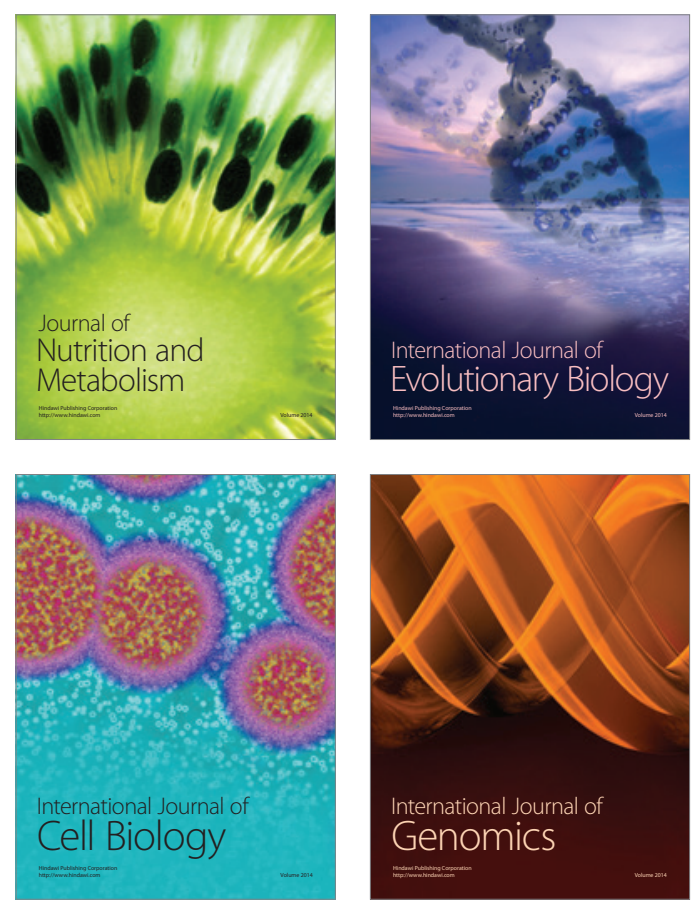
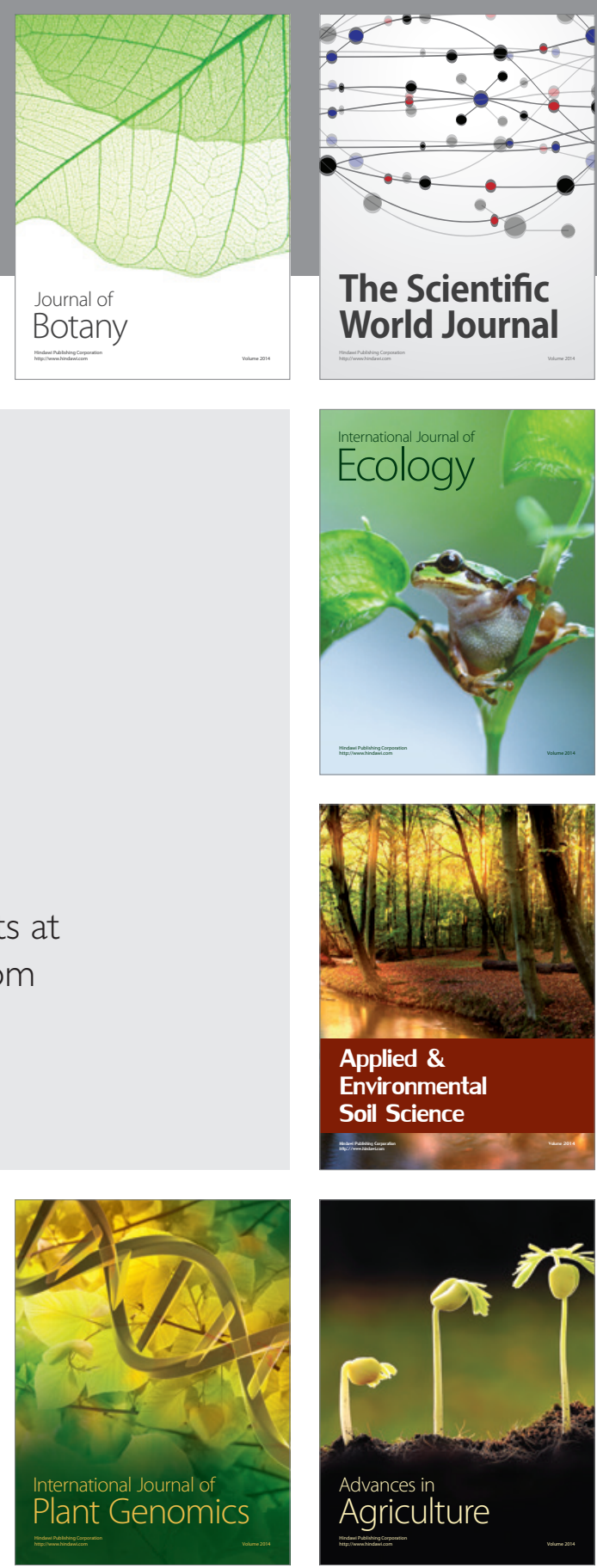

The Scientific World Journal
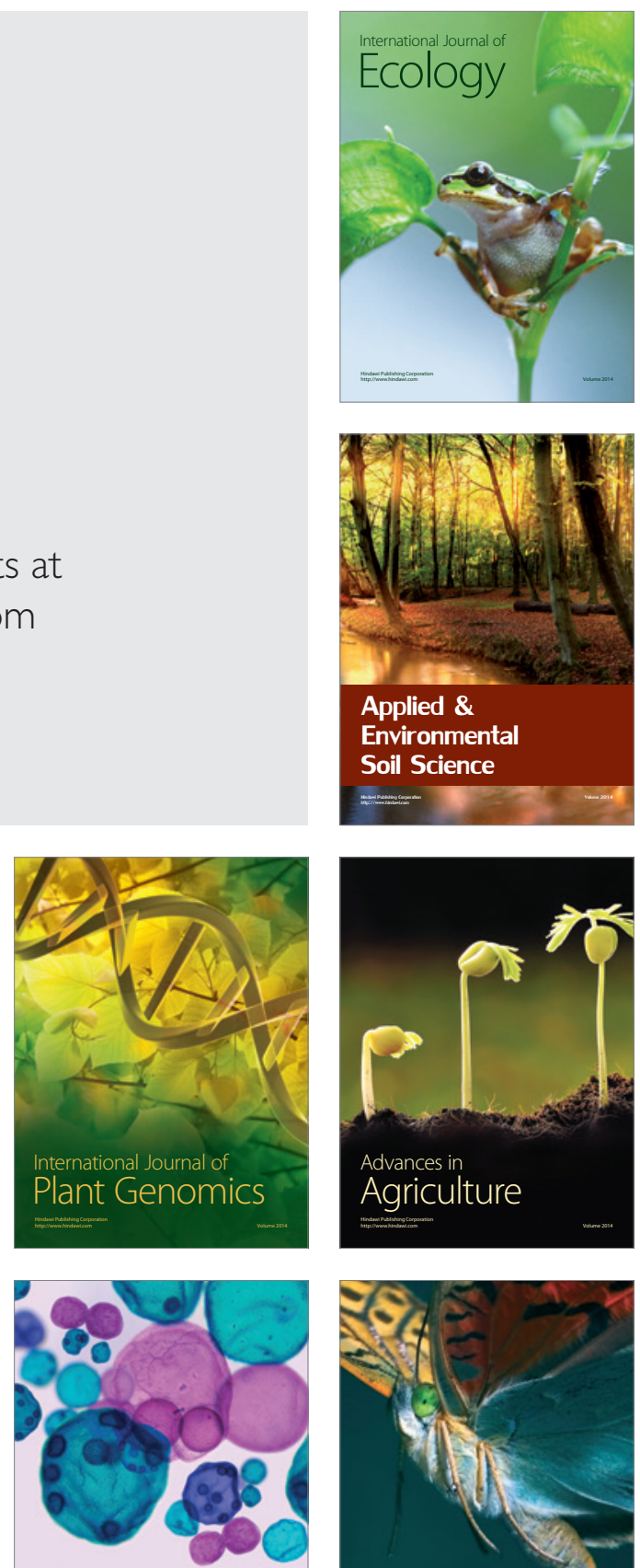

International Journal of Microbiology

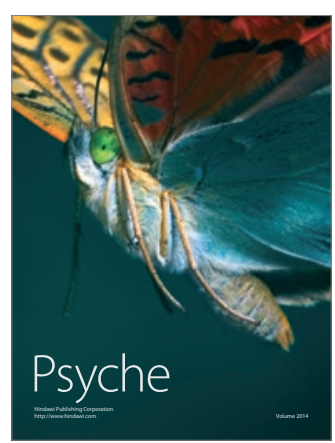

